\title{
In vitro development of day 2 embryos obtained from young, fertile mares and aged, subfertile mares
}

\author{
S. P. Brinsko, B. A. Ball ${ }^{\dagger}$, P. G. Miller, P. G. A. Thomas and \\ J. E. Ellington ${ }^{\ddagger}$ \\ Department of Clinical Sciences, New York State College of Veterinary Medicine, Cornell University, \\ Ithaca, NY 14853, USA
}

\begin{abstract}
This study was designed to investigate the development of day 2 embryos obtained from young and aged mares, co-cultured with oviductal epithelial cells obtained from mares in each age group in a $2 \times 2$ crossover design. Young, fertile mares $(n=19 ; 2-7$ years of age) and aged, subfertile, mares $(n=16 ; 17-24$ years of age) were used as embryo and oviductal epithelial cell donors. Embryos $(n=37)$ were collected from the oviducts 2 days after ovulation and were paired (embryos obtained from young mares with embryos obtained from aged mares) so that eight pairs were co-cultured with young mare oviductal epithelial cells and eight pairs were co-cultured with aged mare oviductal epithelial cells. Five additional embryos obtained from young mares were co-cultured with oviductal epithelial cells from either young mares or aged mares but were not paired. Embryos were co-cultured for 7 days at $38.5^{\circ} \mathrm{C}$ in $5 \% \mathrm{CO}_{2}$ or until morphological degeneration was detected. The proportions of paired embryos that reached the blastocyst stage were similar for embryos obtained from young mares and embryos obtained from aged mares after co-culture with oviductal epithelial cells from young mares ( 6 of 8 versus 5 of 8 ) or from aged mares (6 of 8 versus 5 of 8 ), respectively. Although the overall rate of development of embryos to blastocyst from both young mares and aged mares was similar, blastocysts developing from embryos obtained from aged mares were inferior to blastocysts obtained from young mares in terms of number of cell nuclei, quality score, and diameter at day 7. The results of this experiment indicate that the high rate of early embryonic loss in aged, subfertile mares may be due to inherent developmental defects in their embryos, but does not appear related to the ability of embryos from aged, subfertile mares to reach the blastocyst stage.
\end{abstract}

\section{Introduction}

Reduced fertility as a function of advancing age is a well recognized phenomenon in humans and has been the focus of recent investigations in mares (Ball et al., 1989; Baker et al., 1993; Carnevale et al., 1993). Studies in rats (Day et al., 1991; Mattheij and Swarts, 1991), mice (reviewed by Jones, 1970), cattle (Osoro and Wright, 1992), domestic cats (Legay, 1985), and monkeys (Harley, 1990) indicate that an age-related decline in fertility occurs in a variety of species. This trend greatly affects the equine industry where breeding animals are selected for athletic performance rather than fertility and are maintained in the breeding herd much longer than in other species to capitalize on both the proven and potential performance of their offspring.

${ }^{\dagger}$ Correspondence.

${ }^{\ddagger}$ Current address: Health Research Education Center, Washington State University, West 601 Ist Avenue, Spokane, Washington 99204.

Received 25 April 1994
Several studies have indicated that embryonic loss is a significant contributor to the reduced pregnancy rates observed in subfertile mares. The incidence of embryonic loss 15-50 days after ovulation was found to be higher for subfertile mares (39\%) than for other mares (17\%) (Villahoz et al., 1985), and the day 12 pregnancy rate for aged ( $\geq 15$ years) pony mares $(32 \%)$ was lower than that of young (5-7 years) pony mares $(100 \%)$ (Carnevale and Ginther, 1992). Recovery rates of day 7-10 embryos are lower in subfertile mares than in normal mares (Douglas, 1982; Pascoe et al., 1985; Squires et al., 1985; Woods et al., 1985). In field studies, fertility in mares has been shown to decline with advanced age (Hutton and Meacham, 1969; Lang and Leech, 1975; Woods et al., 1987).

Postulated causes of embryonic loss in aged, subfertile mares include reduced fertilization rate, abnormal oviductal environment, embryonic defects and abnormal uterine environment. Fertilization failure does not appear to be a factor because fertilization rates for young, normal mares (91-96\%) and aged, subfertile mares $(81-92 \%)$ are similar (Ball et al., 1986, 1989). Likewise, in the absence of gross pathology, the uterine 
environment of aged, subfertile mares does not appear to adversely affect embryonic development. When normal day 7 or day 8 embryos were transferred to normal and subfertile recipient mares, embryo survival to day 28 was similar for the two recipient groups (10 of 20 versus 8 of 20 , respectively) (Ball et al., 1987). Transfer of day 4 embyos from young, normal mares and aged, subfertile mares to normal recipient mares resulted in significantly higher day 14 survival rates for embryos obtained from normal mares than for those obtained from subfertile mares (Ball et al., 1989). These results suggest that inherent defects in embryos obtained from aged subfertile mares may be responsible for the higher rates of embryonic loss observed. However, the proportion of day 4 embryos obtained from aged, subfertile mares (13 of 20) was significantly less than that obtained from young, normal mares (23 of 25) (Ball et al., 1989), whereas in a similar experiment (Ball et al., 1986) the proportion of day 2 embryos obtained from these classes of mare (11 of 14 versus 10 of 14) did not differ. Therefore, it is also possible that an adverse oviductal environment may have exerted deleterious effects on the developmental capacity of embryos within the first 4 days after ovulation.

The objective of the present study was to examine maternalage-related embryonic and oviductal influences on equine blastocyst development by comparing the development of day 2 equine embryos obtained from young, fertile and aged, subfertile mares after co-culture with oviductal epithelia obtained from either young, fertile or aged, subfertile mares.

Part of these data has been presented in abstract form (Brinsko et al., 1994).

\section{Materials and Methods}

\section{Reproductive management}

Light-breed horse mares were used as embryo and oviductal epithelial cell donors. Young, normal mares ( $n=19$; age $=$ $4.2 \pm 1.5$ years; $\bar{x} \pm \mathrm{SD}$ ) were obtained at public auction. Aged, subfertile mares $(n=16$; age $=20.0 \pm 2.4$ years; $\bar{x} \pm \mathrm{SD}$ ), obtained via donation through the cooperation of veterinary practitioners and breeders, were multiparous, but had not foaled for at least two years before the onset of the study despite numerous breedings. The reproductive tracts of mares were screened for anatomical defects and signs of inflammation via transrectal palpation, ultrasonography, endometrial cytology and endometrial biopsy (Neely, 1983). Any mare demonstrating moderate to severe endometrial inflammation underwent further diagnostic tests and appropriate endometrial therapy to resolve the problem before continuing in the study. Mares were maintained in drylots and fed a diet of grass, hay and water ad libitum with sufficient grain to maintain good body condition.

Oestrous cycles of the mares were synchronized with $10 \mathrm{mg}$ PGF $_{2 \alpha}$ (Lutalyse: Upjohn, Kalamazoo, MI) so that they could be paired by age-group for embryo and oviductal epithelial cell recovery. Daily teasing with an active stallion was used to determine the onset of oestrus. On the second day of behavioural oestrus, mares were examined via transrectal palpation and ultrasonography. Examinations continued every other day until a follicle measuring $\geq 30 \mathrm{~mm}$ in diameter was observed. Thereafter, examinations were performed daily until ovulation was detected (day 0). Upon detection of a follicle $\geq 35 \mathrm{~mm}$ in diameter, mares were inseminated every other day with a minimum of $5 \times 10^{8}$ progressively motile spermatozoa from a fertile stallion until detection of ovulation. Semen was extended in Kenney's non-fat dry skim milk-glucose extender containing $1 \mathrm{mg}$ ticarcillin $\mathrm{ml}^{-1}$ (Ticar: Smith Kline Beecham, Philadelphia, PA). Mares received 1500 iu hCG (Henry Schein Inc., Port Washington, NY) i.v. on the day following the first insemination. Embryos were recovered $48-58 \mathrm{~h}$ after ovulation was detected. To facilitate pairing of embryos from young and aged mares, surgery for embryo recovery was only performed when a mare in the opposite age/fertility group was also expected to be within 8 days of ovulation. Synchronized mares that were not inseminated or that did not undergo embryo recovery were given $10 \mathrm{mg} \mathrm{PGF}_{2 u}$ i.m. at least 6 days after ovulation, so that they could be used in a subsequent pairing scheme.

\section{Embryo collection}

Surgical recovery of embryos from the oviduct was performed as described by Ball $e t$ al. (1989). The oviduct on the side of ovulation was removed via flank laparotomy, and the excised oviduct was flushed for embryo recovery. Immediately before surgery, an endometrial biopsy was obtained from each mare, fixed in Bouin's solution, then transferred to $70 \%(\mathrm{v} / \mathrm{v})$ ethanol until stained with haematoxylin and eosin for routine histopathological examination. Endometrial biopsies were categorized according to the method of Kenney and Doig (1986).

Embryos were flushed from the excised oviduct with $10-15 \mathrm{ml}$ of Dulbecco's modified PBS containing $10 \%(\mathrm{v} / \mathrm{v})$ fetal bovine serum (FBS; Hyclone, Langhorne, $\mathrm{PA}$ ) into small drops in a $100 \mathrm{~mm}$ Petri dish. Oviduct flushes were repeated up to three times by cannulating the isthmus with a blunt 22-28 gauge needle. If no embryo was recovered by this means, the ampulla was cannulated with a blunt 18 gauge needle and the oviduct was flushed in the opposite direction. Recovered embryos were rinsed through three passages of fresh culture medium (previously equilibrated in the incubator for at least $1 \mathrm{~h}$ ), assessed for morphological development and quality score, and photographed. Quality scores of embryos at recovery and throughout the culture period were assigned as follows: $I=$ excellent - spherical, homogeneous cell size, colour and texture; $2=$ good - minor imperfections, few extruded cells, slightly heterogeneous cell size, colour or texture; 3 = fair - obvious but not severe problems, extruded cells, degenerate cells, heterogeneity of cells, colour or texture, irregular shape; $4=$ poor/degenerate - severe problems, numerous extruded cells, dark, fragmented cells, collapsed blastocoel, irregular shape. Recovered embryos were paired to oviductal epithelial cell co-culture type (i.e. cells from either young or aged mares) so that an embryo obtained from an aged, subfertile mare and a paired embryo obtained from a young, fertile mare were co-cultured with cells obtained from the same donor. 


\section{Embryo culture}

Oviductal epithelial cell cultures were set up from each mare at the time of embryo recovery and were used for co-culture with subsqeuent embryos. Culture wells containing oviductal epithelial cells were set up at least 2 days before the start of embryo co-culture to allow equilibration and conditioning of media. Co-culture of embryos was initiated after at least 2 days but within 10 days of oviductal epithelial cell collection. Selection of oviductal epithelial cell vesicles was based on homogeneity of colour and presence of ciliary beat. To ensure adequate numbers of embryo and oviductal epithelial cell pairs for comparison, preference was initially given to co-culture with oviductal epithelial cells obtained from aged mares when both types of oviductal epithelial cell were suitable, since the number of aged donors was limited. All culture reagents were obtained from Sigma (St Louis, MO) and a single lot number of each reagent was used for the entire experiment. Culture medium consisted of Ham's F-12 and Dulbecco's modified Eagle's medium (50:50, v:v) with $29 \mathrm{mmol} \mathrm{NaHCO}_{3} \mathrm{l}^{-1}, 5 \mu \mathrm{g}$ insulin $\mathrm{ml}^{-1}, 5 \mu \mathrm{g}$ transferrin $\mathrm{ml}^{-1}, 5 \mathrm{ng}$ sodium selenite $\mathrm{ml}^{-1}, 50$ iu penicillin $\mathrm{ml}^{-1}$, and $50 \mu \mathrm{g}$ streptomycin $\mathrm{ml}^{-1}$, and $10 \mathrm{ng}$ epidermal growth factor $\mathrm{ml}^{-1}$. Culture conditions consisted of $5 \% \mathrm{CO}_{2}$ in humidified air at $38.5^{\circ} \mathrm{C}$. Because of the bicarbonate buffer in this media, culture droplets were allowed to equilibrate for at least $\mathrm{I} \mathrm{h}$ in the incubator before use for embryo culture. Embryos were co-cultured in $500 \mu \mathrm{l}$ of medium in one well of a 24-well plate along with oviductal epithelial cell vesicles produced from scrapings from the ampullae of oviducts collected at day 2 (Ball and Miller, 1992). A maximum of two embryos, one each from aged and young mares, were incubated per plate to equalize handling conditions. In most instances, a single embryo was incubated per plate. Each experimental cell consisted of one of the following culture wells: a day 2 embryo from a young mare with oviductal epithelial cells from a young mare $(n=12)$, a day 2 embryo from an aged mare with oviductal epithelial cells from a young mare $(n=8)$, a day 2 embryo from a young mare with oviductal epithelial cells from an aged mare $(n=9)$, and a day 2 embryo from an aged mare with oviductal epithelial cells from an aged mare $(n=8)$. Five embryos obtained from young mares (four co-cultured with young mare oviductal epithelial cell and one co-cultured with aged mare oviductal epithelial cells) were not paired with corresponding embryos from aged mares.

At $20-30 \mathrm{~h}$ intervals, embryos were assessed for stage of development and quality score and then photographed. Morphological evaluation was performed daily for 7 days after collection for the majority of embryos $(n=27)$. Two embryos were inadvertently cultured for 8 days and the remaining embryos $(n=8)$ were fixed earlier than 7 days if they were determined to be morphologically degenerated for two consecutive days in culture $(n=7)$, or if blastocyst hatching was evident before 7 days in culture $(n=1)$. Embryos were fixed in $2 \%(\mathrm{v} / \mathrm{v})$ glutaraldehyde with $2.5 \%(\mathrm{v} / \mathrm{v})$ paraformaldehyde and $0.1 \mathrm{~mol}$ cacodylate $\mathrm{l}^{-1}$ and then stained with Hoechst 33342 in order to determine total cell numbers and numbers of pyknotic nuclei (Critser and First, 1986). Embryo diameters (zonae not included) at detection of blastulation and at day 7 of culture were measured from their corresponding photographs.
Table 1. Number of endometrial biopsies (\%) in Kenney/Doig categories obtained from young and aged mares 2 days after ovulation

\begin{tabular}{|c|c|c|c|c|c|c|}
\hline \multirow[b]{2}{*}{ Mares } & \multicolumn{4}{|c|}{ Biopsy categories ${ }^{a}$} & \multirow[b]{2}{*}{ Total } & \multirow[b]{2}{*}{ Median } \\
\hline & I & IIA & IIB & III & & \\
\hline Aged & $1 \quad(7)$ & $4(29)$ & $7(50)$ & $2(14)$ & 14 & IIB* \\
\hline Young & $6(32)$ & $12(63)$ & I (5) & $0 \quad(0)$ & 19 & IIA* $^{*}$ \\
\hline Total & 7 & 16 & 8 & 2 & 33 & \\
\hline
\end{tabular}

a(1) normal (70-90\% foaling rate), (IIA) mild endometrial histological changes (50-70\% foaling rate), (IIB) moderate endometrial histological changes (10$50 \%$ foaling rate), (III) severe endometrial histological changes $(<10 \%$ foaling rate).

*Medians are significantly different $(P<0.001)$.

\section{Statistical analyses}

Embryo recovery rates (both number of embryos/number of oviducts flushed and number of embryos/number of ovulations) and fertilization rates (number of embryos/(number of embryos + number of recently ovulated ova)) were compared by chi-square analysis (Dawson-Saunders and Trapp, 1990). Comparisons of the proportions of paired embryos developing to blastocyst stage were performed via McNemar chi-square analysis (Fleiss, 1981). Differences in biopsy categories, embryo recovery by biopsy category, embryo quality score, blastocyst diameter, number of cells, pyknotic nuclei, and days required to reach blastocyst stage were determined using Wilcoxon Rank Sum/Mann-Whitney U analysis (Hollander and Wolfe, 1973). This more conservative, non-parametric analysis was used for the ordinal data (i.e. biopsy category and quality score) and also for the remainder of the data since assumptions of normality and equal variance were suspect, owing to frequent small or unequal sample sizes. Comparisons were analysed by oviductal epithelial cell and embryo type within the $2 \times 2$ design.

\section{Results}

Mares aged 17-24 years had more severe endometrial histologic changes than did mares aged $2-7$ years $(P<0.001$; Table 1). Day 2 embryo recovery rates/ovulation were significantly higher for young mares than for aged mares $(P<0.01$; Table 2). However, median endometrial biopsy score was not related to embryo recovery. Estimated fertilization rates and day 2 embryo recovery rates/oviduct flushed were significantly higher for young mares than for aged mares $(P<0.01$; Table 2).

\section{Development to blastocyst}

The proportion of paired embryos that reached the blastocyst stage were similar for embryos obtained from young mares and embryos obtained from aged mares after co-culture with oviductal epithelial cells regardless of whether they were obtained from young or aged mares (Table 3). No significant differences were detected when days to reach blastocyst, 
Table 2. Day 2 embryo recovery and fertilization rates for normal and subfertile mares

\begin{tabular}{lcc}
\hline & $\begin{array}{c}\text { Young normal } \\
\text { mares }(\%)\end{array}$ & $\begin{array}{c}\text { Aged subfertile } \\
\text { mares }(\%)\end{array}$ \\
\hline $\begin{array}{l}\text { Fertilization rate } \\
\text { Number of embryos/ } \\
\text { number of oviducts flushed }\end{array}$ & $\begin{array}{c}24 / 24(100) \\
24 / 26(92)\end{array}$ & $16 / 20^{*}(80)$ \\
$\begin{array}{c}\text { Number of embryos/ } \\
\text { number of ovulations }\end{array}$ & $24 / 26(89)$ & $16 / 31^{* *}(57)$
\end{tabular}

${ }^{a}$ Estimated at day 2 by: number of embryos/(number of embryos + number recently ovulated unfertilized ova).

${ }^{*} P<0.05 ;{ }^{* *} P<0.01$ compared with young, normal mares.

Table 3. Development to blastocyst of paired equine embryos co-cultured with oviductal epithelial cells from young mares or aged mares

\begin{tabular}{lccc}
\hline Embryo/OEC & Young mare \\
OEC & $\begin{array}{c}\text { Aged mare } \\
\text { OEC }\end{array}$ & Total \\
\hline Young mare embryos & $6 / 8$ & $6 / 8$ & $12 / 16$ \\
Aged mare embryos & $5 / 8$ & $5 / 8$ & $10 / 16$ \\
Total & $11 / 16$ & $11 / 16$ & $22 / 32$ \\
\hline
\end{tabular}

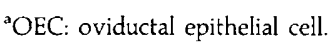

diameters at blastocyst, or per cent pyknotic nuclei/blastocyst, were analysed by embryo or oviductal epithelial cell type.

\section{Quality score and blastocyst diameters}

The overall development of embryos obtained from aged mares $(n=16)$ was inferior to that of embryos obtained from young mares ( $n=21$; includes five unpaired embryos), and the source of oviductal epithelial cells tended to influence development based on quality score, diameter and total cells per blastocyst. On the day blastulation was detected, quality scores of embryos were better overall for young mare embryos $(n=16)$ than for aged mare embryos $(n=9)$ regardless of oviductal epithelial cell type (Table 4; $P \leqslant 0.01$ ). On day 7 of culture, blastocyst quality score was again superior $(P<0.01)$ for young mare embryos $(n=15)$ compared with embryos from aged mares $(n=9)$ regardless of oviductal epithelial cell co-culture type (Table 4). Blastocyst diameter on day 7 of co-culture also tended to be larger $(P=0.12)$ for embryos obtained from young, fertile mares than for embryos obtained from aged, subfertile mares. Blastocyst quality scores and blastocyst diameters at day 7 were superior for embryos from young mares compared with embryos from aged mares when co-cultured with oviductal epithelial cells from young mares. However, these differences were not significant for embryos co-cultured with oviductal epithelial cells from aged mares (Table 4; Fig. 1). Although median day 7 diameters tended to be larger for young mare embryos co-cultured with young mare oviductal epithelial cells than young mare
Table 4. Median quality scores of equine blastocysts by type of oviductal epithelial cell co-culture

\begin{tabular}{|c|c|c|c|}
\hline Embryo donor & OEC donor & $\begin{array}{l}\text { Quality score* } \\
@ \text { blastocyst } \\
(n) \text { [Quartiles] }\end{array}$ & $\begin{array}{l}\mathrm{D} 7^{\dagger} \text { quality score } \\
(n) \text { [Quartiles] }\end{array}$ \\
\hline Young & Young & $\begin{array}{c}2.0(9)^{\mathrm{a}} \\
{[1.5,2.5]}\end{array}$ & $\begin{array}{l}1.5(8)^{\text {ae }} \\
{[1.5,2.0]}\end{array}$ \\
\hline Young & Aged & $\begin{array}{c}2.0(7)^{c} \\
{[1.5,2.0]}\end{array}$ & $\begin{array}{cc}1.5 & (7) \\
{[1.5,} & 2.5\end{array}$ \\
\hline Young & Combined & $\begin{array}{l}2.0(16)^{\mathrm{e}} \\
{[1.5,2.4]}\end{array}$ & $\begin{array}{l}1.5(15)^{\mathrm{g}} \\
{[1.5,2.0]}\end{array}$ \\
\hline Aged & Young & $\begin{array}{cc}2.5 & (4) \\
{[2.0,3.0]}\end{array}$ & $\begin{array}{c}2.5 \quad(4)^{f} \\
{[2.13,2.5]}\end{array}$ \\
\hline Aged & Aged & $\begin{array}{c}3.0(5)^{\mathrm{bd}} \\
{[2.25,3.0]}\end{array}$ & $\begin{array}{cc}2.5 & (5)^{b} \\
{[2.0,3.5]}\end{array}$ \\
\hline Aged & Combined & $\begin{array}{c}3.0 \quad(9)^{f} \\
{[2.0,3.0]}\end{array}$ & $\begin{array}{c}2.5(9)^{h} \\
{[2.25,3.0]}\end{array}$ \\
\hline
\end{tabular}

OEC: oviductal epithelial cells.

*Quality scores: (1) excellent, (2) good, (3) fair, (4) poor/degenerate.

${ }^{\dagger}$ D7 = Day 7 of co-culture.

Within columns, comparisons with different superscripts are significantly different: $\mathrm{a}, \mathrm{b} ; \mathrm{c}, \mathrm{d}(P<0.05)$; e, f; $\mathrm{g}, \mathrm{h}(P \leq 0.01)$.

embryos co-cultured with aged mare oviductal epithelial cells, differences were not significant $(P=0.23$; Fig. 1 ).

\section{Number of blastocyst cells}

Five young mare embryos and two aged mare embryos were lost in handling or could not be used after staining with Hoechst 33342 and so were not included in the analysis of total number of cells per blastocyst. The median number of cells in blastocysts that developed from aged mare embryos was lower (but the difference was not statistically significant) than that of blastocysts which developed from young mare embryos regardless of the type of oviductal epithelial cell co-culture $(P=0.10$; Fig. 2). Median cell number for all blastocysts (derived from both young and aged mare embryos) co-cultured with oviductal epithelial cells from young, fertile mares $(n=8)$ tended $(P=0.12)$ to be greater than for embryos co-cultured with oviductal epithelial cells from aged, subfertile mares $(n=11)$. However, the median number of cells of aged mare embryos co-cultured with oviductal epithelial cells from young mares was lower than that of young mare embryos co-cultured with oviductal epithelial cells from young mares (Fig. 3). The number of cells in blastocysts after 7 days of co-culture was affected by both embryo and oviductal epithelial cell type (Fig. 4).

\section{Discussion}

In the present study, the estimated fertilization rate for young mares was higher than that for aged, subfertile mares. However, Ball et al. (1986) estimated fertilization rates for normal mares and aged, subfertile mares did not differ. Embryos per ovulation in normal and aged mares in the earlier study (Ball et al., 1986) 


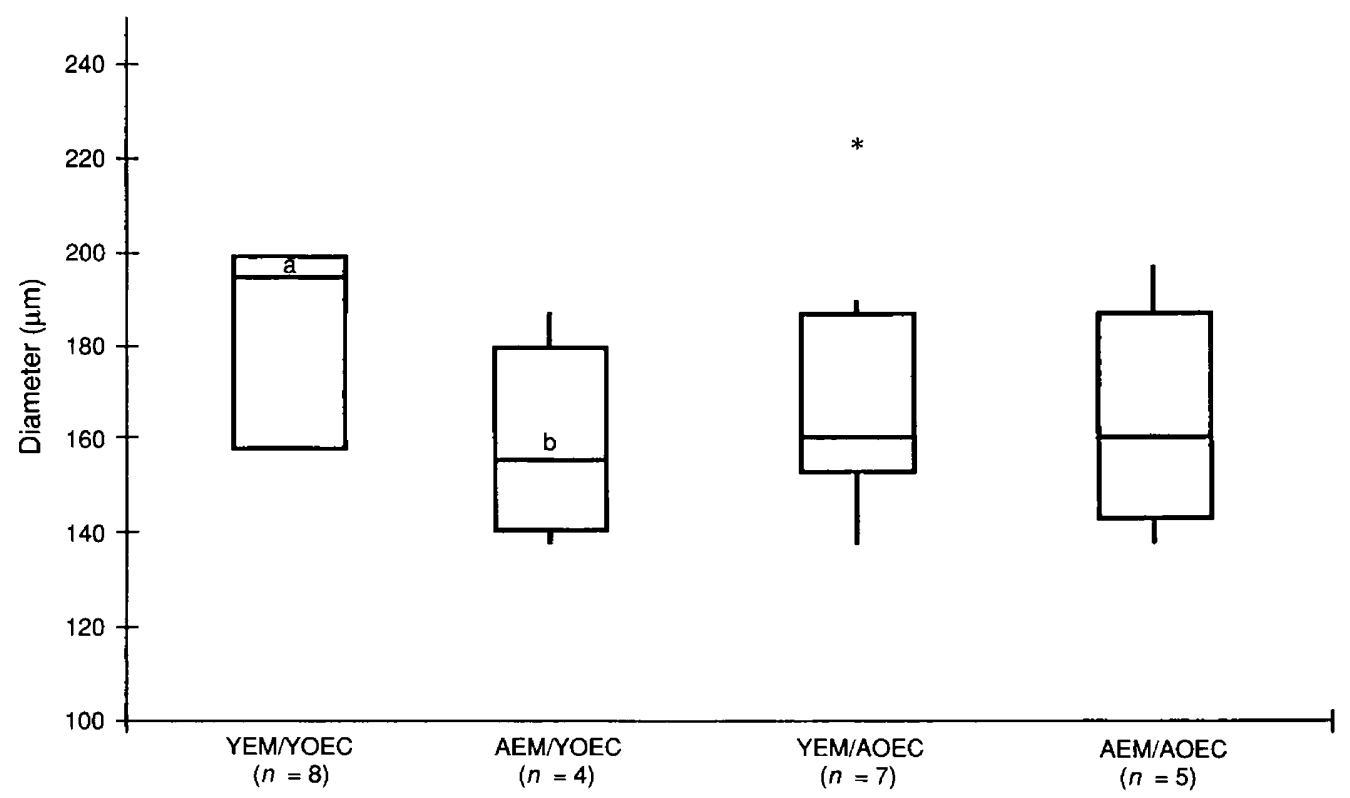

Fig. 1. Box and whisker plots of blastocyst diameters $(\mu \mathrm{m})$ after 7 days of co-culture with oviductal epithelial cells (OECs). Box encloses data between the first and third quartile and is bisected by a line at the median value. Vertical lines indicate range of typical values and * indicates a possible outlier. YEM: embryos from young mares; AEM: embryos from aged mares; YOEC: oviductal epithelial cells from young mares; AOEC: oviductal epithelial cells from aged mares; / indicates 'co-cultured with'. $a, b(P \leqslant 0.1)$.

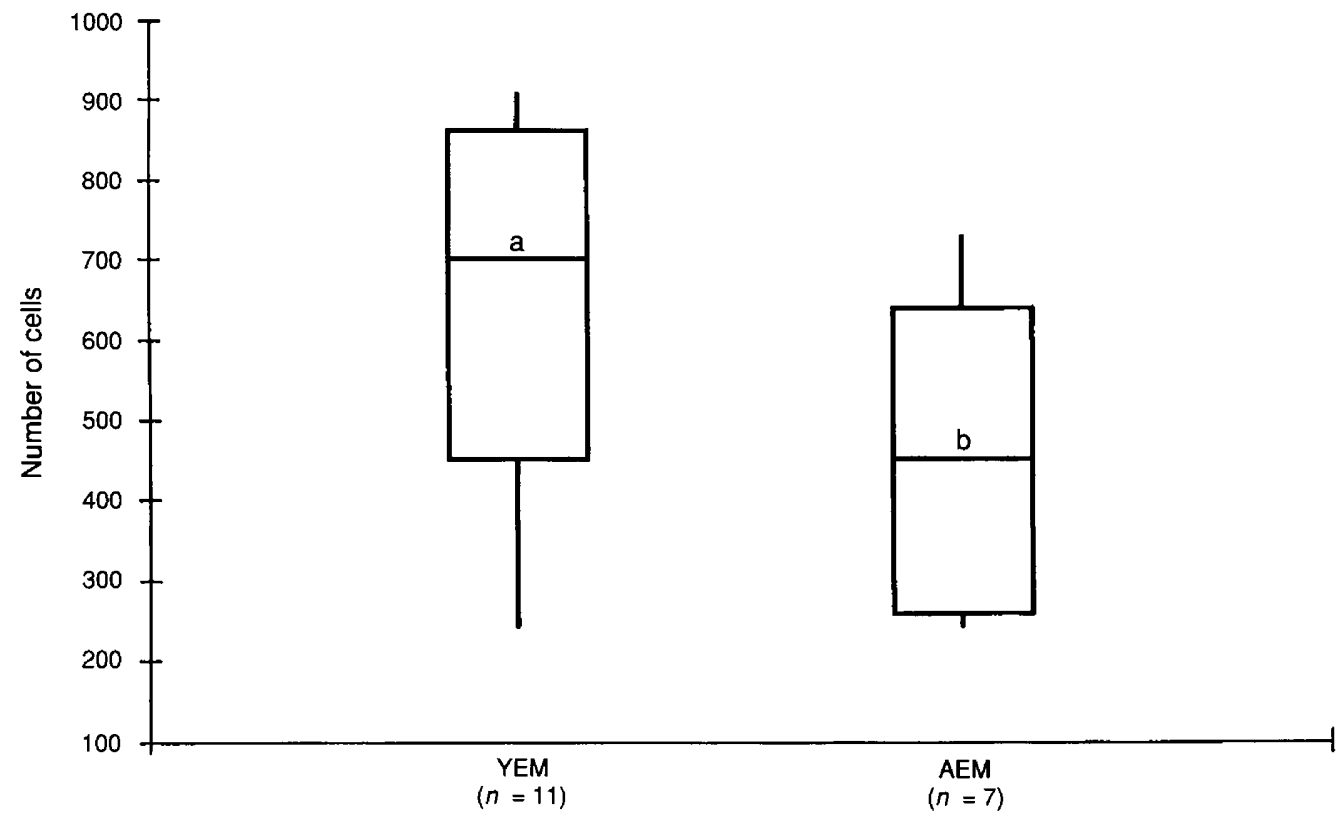

Fig. 2. Box and whisker plots of the number of cells in equine blastocysts after 7 days of co-culture with oviductal epithelial cells. Box encloses data between the first and third quartile and is bisected by a line at the median value. Vertical lines indicate range of typical values. YEM: embryos from young mares; AEM: embryos from aged mares. $\mathrm{a}, \mathrm{b}(P \leqslant 0.1)$.

were also similar, but again differed in the present study. The reasons for these discrepancies are unclear but results of the present study may indicate an alteration of normal oviductal function in aged, subfertile mares. These alterations could have interfered with the ability of the oviduct to capture or transport ova thus disrupting the normal processes of fertilization and embryonic development. Henry and Vandeplassche (1981) reported a higher frequency of infundibular adhesions and infundibulitis in aged mares. However, such abnormalities were not apparent in the present study.

The finding that day 2 embryos from aged, subfertile mares were able to reach the blastocyst stage in similar proportions to 

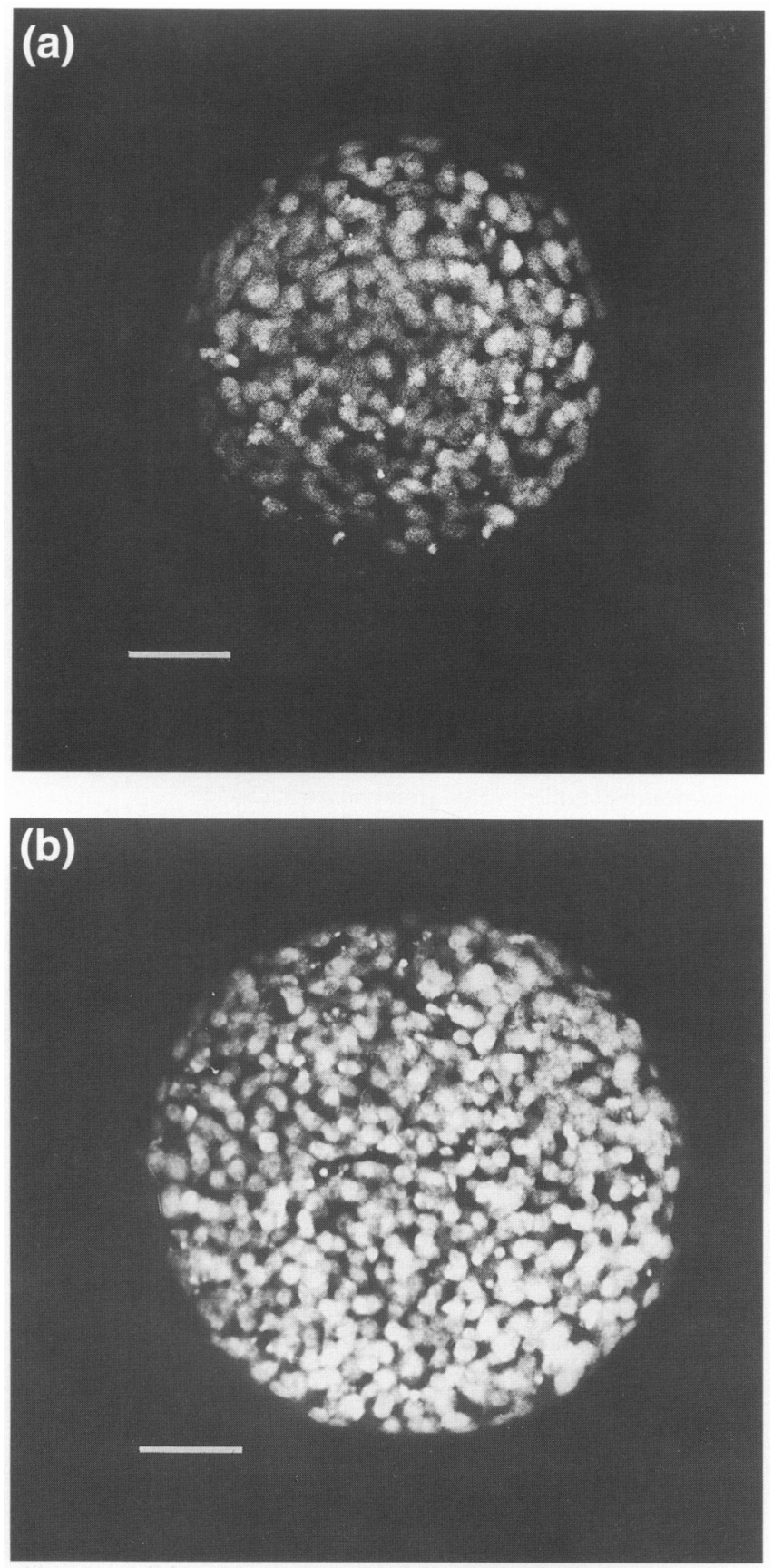

Fig. 3. Photomicrographs of equine blastocysts stained with Hoechst 33342 after 7 days of co-culture with oviductal epithelial cells and viewed with epifluorescence. Scale bars represent $50 \mu \mathrm{m}$. (a) Blastocyst developed from day 2 embryo obtained from an aged mare co-cultured with oviductal epithelial cells obtained from a young mare. (b) Blastocyst from day 2 embryo obtained from a young mare co-cultured with oviductal epithelial cells obtained from a young mare.

those from young, fertile mares was unexpected, especially in light of similar studies that found pregnancy rates to be similar for young and aged mares at day 2 (Ball et al., 1986) but lower for aged mares at day 4 (Ball et al., 1989). Despite this result, the present study provides evidence (quality score, cell number and embryo diameter) that the developmental capacity of equine embryos in vitro is affected by maternal age. Even though similar proportions of embryos from young and aged mares reached the blastocyst stage in vitro, inferior embryos from aged, subfertile mares may not be able to establish detectable pregnancy in vivo. This hypothesis is supported by embryo transfer studies which found recovery rates at days $7-10$ to be lower in subfertile mares than in normal mares (Douglas, 1982; Pascoe et al., 1985; Squires ef al., 1985; Woods et al., 1985), as well as the study by Ball et al. (1986) which found a significant difference in day 14 pregnancy rate between young and aged mares, but no difference in day 2 pregnancy rate for these mares.

In most mammalian species, both embryos and unfertilized oocytes are transported into the uterus (Harper, 1988). In mares, viable embryos are preferentially transported into the uterus while oocytes (Betteridge and Mitchell, 1974) and developmentally arrested embryos (Betteridge et al., 1979) are retained in the oviduct. Equine embryos normally enter the uterus 5-6 days after ovulation (Oguri and Tsutsumi, 1972; Betteridge et al., 1982; Freeman et al., 1991) when they are compact morulae or early blastocysts. The signal for transport into the uterus appears to be embryo-derived $\mathrm{PGE}_{2}$ (Weber et al., 1991a, b; 1992a; Freeman et al., 1992). Embryonic synthesis and secretion of $\mathrm{PGE}_{2}$ is first detectable on day 5 after ovulation and increases significantly thereafter (Weber et al., 1991a) and the rate of secretion is positively correlated with embryo diameter (Weber et al., 1992b). Therefore, it can be hypothesized that $\mathrm{PGE}_{2}$ synthesis and secretion by equine embryos is dependent on their developmental status and that embryos whose development has been impaired may suffer a delay in or failure of oviductal transport. A delay in transport could result in a failure to maintain pregnancy after day 14 because the embryo may not be developmentally competent to inhibit endometrial $\mathrm{PGF}_{2 u}$ secretion from inducing luteolysis. Although apparently inferior embryos reached the blastocyst stage in the present in vitro study, inferior embryos in vivo may be unable to initiate their transport into the uterus at the appropriate time to allow establishment of pregnancy.

Defective embryos from aged, subfertile mares probably arise from defective ova. However, oviductal influences may also contribute to the inferior development of these embryos. The former hypothesis is supported by previous studies (Ball et al., 1986, 1987, 1989). Studies of infertile human patients also provide indications of effects of the ova (Levran ef al., 1991; Navot et al., 1991; Rotsztejn et al., 1992; Sauer et al., 1992; Abdalla et al., 1993) and oviduct (Balasch et al., 1992). Research involving gamete intrafallopian transfer (GIFT) or zygote intrafallopian transfer (ZIFT) with oocytes obtained from young donors transferred to aged recipients would be helpful in further elucidating the contribution of oviductal environment to infertility.

In the present study, for all groups of comparisons where significant differences were detected (i.e. quality scores at blastulation and day 7, embryo diameter at day 7 and cells per blastocyst), embryos obtained from young, fertile mares were consistently superior to embryos obtained from aged, subfertile mares, demonstrating that embryos from young, normal mares have a greater inherent developmental capacity than do embryos from aged, subfertile mares. The contribution of 


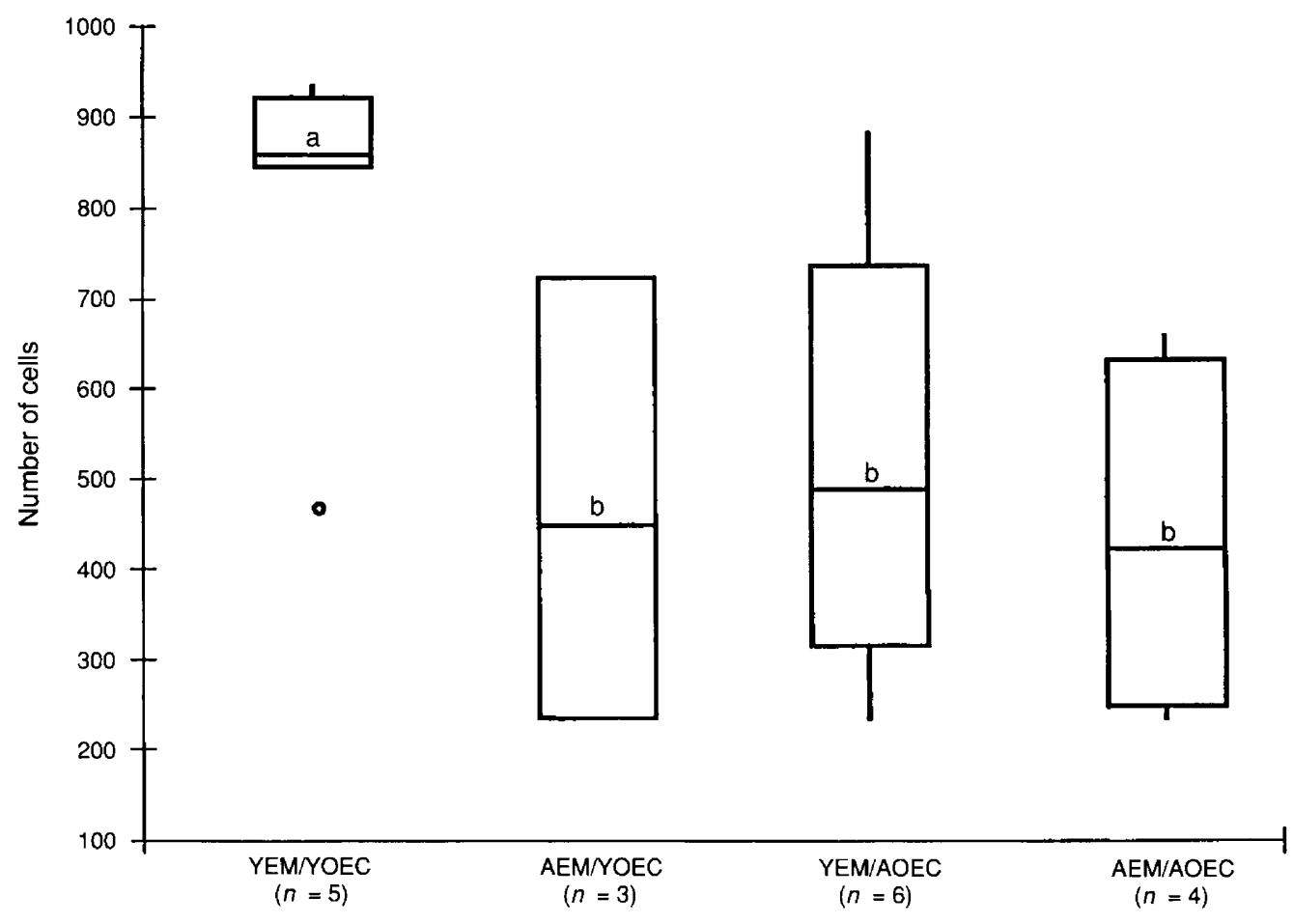

Fig. 4. Box and whisker plots of the number of cells in equine blastocysts after 7 days of co-culture with oviductal epithelial cells. Box encloses data between the first and third quartile and is bisected by a line at the median value. Vertical lines indicate range of typical values and $\mathbf{o}$ indicates a probable outlier. YEM: embryos from young mares; AEM: embryos from aged mares. YOEC: oviductal epithelial cells from young mares; AOEC: oviductal epithelial cells from aged mares; / indicates 'co-cultured with'. a,b $(P<0.1)$.

oviductal influence, however, remains uncertain. Quality scores for young mare embryos co-cultured with aged mare oviductal epithelial cells were superior to aged mare embryos co-cultured with aged mare oviductal epithelial cells indicating an embryo effect, yet there was no difference between embryos from young mares and aged mares when both were co-cultured with oviductal epithelial cells from young mares. These results although puzzling, may relate to the subjectivity of quality scores. Although quality score is probably the most widely used criterion for embryo selection, embryos of normal appearance may not be competent to develop normally. Supportive evidence for this comes from a study by Wimmers and Van der Merwe (1988), in which they evaluated chromosomal complements in human IVF embryos and found numerical abnormalities in $71.7 \%$ of embryos of normal appearance.

In the present study, a significant difference was not apparent in any direct comparisons of oviductal epithelial cells obtained from young mares and those obtained from aged mares. However, in what appeared to be the most sensitive assessment of developmental capacity, i.e. total cells per blastocyst, there was a tendency for more cells in embryos co-cultured with oviductal epithelial cells from young, fertile mares than in embryos co-cultured with oviductal epithelial cells from aged, subfertile mares. No differences were detected for any group of comparisons examined for the effect of oviductal epithelial cell type on embryos obtained from aged, subfertile mares. This finding suggests that any beneficial effect that oviductal epithelial cells from young, fertile mares may have had on aged mare embryos have been obscured by the inferior developmental capacity of embryos from aged, subfertile mares in these comparisons, and that the oviductal epithelial cells from young mares were unable to 'rescue' aged mare embryos possessing inherent developmental defects. In addition, use of non-parametric statistical tests, such as the Wilcoxon Rank Sum/Mann-Whitney U test used for these analyses, are more conservative than parametric tests such as Student's $t$-test. Therefore, the tendency towards more cells in embryos co-cultured with young mare oviductal epithelial cells, despite the use of more conservative tests and low power, strongly suggests that there is an age-related oviductal influence.

In conclusion, the results of this experiment indicate that the high rate of early embryonic loss previously reported in aged, subfertile mares may be due to inherent developmental defects in their embryos, but does not appear to be related to the ability of embryos from aged mares to reach the blastocyst stage in vitro. However, this study does provide evidence that the developmental capacity of equine embryos is affected by maternal age. Defective embryos from aged, subfertile mares may arise from defective ova; however, oviductal influences may also contribute to the inferior development of these embryos.

This study was supported by USDA grant no. 91-37203-6552. S. P. Brinsko and P. G. A. Thomas were recipients of a Graduate Rotating Assistantship awarded by the College of Veterinary Medicine, Cornell University. The authors thank $\mathrm{H}$. Erb, who provided invaluable assistance with the statistical analysis and experimental design, and L. Tidd and L. Pautler for their technical assistance. 


\section{References}

Abdalla HI, Burton G, Kirkland A, Johnson MR, Leonard T, Brooks AA and Studd JWW (1993) Age, pregnancy and miscarriage: uterus versus ovarian factors Human Reproduction 8 1512-1517

Baker CB, Little TV and McDowell (1993) The live foaling rate per cycle in mares Equine Veterinary Journal Supplement 15 28-30

Balasch J, Fabregues F, Jove IC, Carmona F and Vanrell JA (1992) Infertility factors and pregnancy outcome in women above age 35 Gynecological Endocrinology 6 31-35

Ball BA and Miller PG (1992) Survival of equine embryos co-cultured with equine oviductal epithelium from the four- to eight-cell to the blastocyst stage after transfer to synchronous recipient mares Theriogenology 37 979-991

Ball BA, Little TV, Hillman RB and Woods GL (1986) Pregnancy rates at days 2 and 14 and estimated embryonic loss rates prior to day 14 in normal and subfertile mares Theriogenology 26 611-619

Ball BA, Hilman RB and Woods GL (1987) Survival of equine embryos transferred to normal and subfertile mares Theriogenology 28 167-174

Ball BA, Little TV, Weber JA and Woods GL (1989) Viability of day-4 embryos from young, normal mares and aged, subfertile mares after transfer to normal recipient mares Journal of Reproduction and Fertility 85 187-194

Betteridge KJ and Mitchell D (1974) Direct evidence of retention of unfertilized ova in the oviduct of the mare Joumal of Reproduction and Fertility 39 145-148

Betteridge KJ, Eaglesome MD and Flood PF (1979) Embryo transport through the mare's oviduct depends on cleavage and is independent of the ipsilateral corpus luteum Journal of Reproduction and Fertility Supplement 27 387-394

Betteridge KJ, Eaglesome MD, Mitchell D, Flood PF and Beriault R (1982) Development of horse embryos up to twenty two days after ovulation: observation on fresh specimens Journal of Anatomy 135 191-209

Brinsko SP, Ball BA, Miller PG, Thomas PGA and Ellington JE (1994) In vitro development of day two embryos obtained from young, fertile or aged, subfertile mares Theriogenology 41 Abstract 209

Carnevale EM and Ginther OJ (1992) Relationships of age to uterine function and reproductive efficiency in mares Theriogenology 37 1101-II15

Carnevale EM, Griffin PG and Ginther OJ (1993) Age-associated subfertility before entry of embryos into the uterus in mares Equine Veterinary Journal Supplement 15 31-35

Critser ES and First NL (1986) Use of a fluorescent stain for visualization of nuclear material in living oocytes and early embryos Stain Technology 61 $1-5$

Dawson-Saunders B and Trapp RG (1990) Estimating and comparing proportions. In Basic and Clinical Biostatistics pp 142-160 Ed. C Beal. Appleton and Lange, Norwalk

Day JR, LaPolt PS and Lu JKH (1991) Plasma patterns of prolactin, progesterone, and estradiol during early pregnancy in aging rats: relation to embryonic development Biology of Reproduction 44 786-790

Douglas RH (1982) Some aspects of equine embryo transfer Journal of Reproduction and Fertility Supplement 32 405-408

Fleiss JL (1981) The analysis of data for matched samples In Statistical Methods for Rates and Proportions pp 112-137 John Wiley and Sons, New York

Freeman DA, Weber JA, Geary RT and Woods GL (1991) Time of embryo transport through the mare oviduct Theriogenology 36 823-830

Freeman DA, Woods GL, Vanderwall DK and Weber JA (1992) Embryo-initiated oviductal transport in mares Journal of Reproduction and Fertility 95 535-538

Harley D (1990) Aging and reproductive performance in langur monkeys (Presbytis entellus) American Journal of Physical Anthropology 83 253-261

Harper MJK (1988) Gamete and zygote transport. In The Physiology of Reproduction Vol I pp 103-134 Eds E Knobil and JD Neill. Raven Press, New York

Henry M and Vandeplassche M (1981) Pathology of the oviduct in mares Vlaams Diergeneeskundig Tijdschrift $50301-325$
Hollander M and Wolfe DA (1973) Two sample location problem. In Nonparametric Statistical Methods pp 67-82. John Wiley and Sons, New York

Hutton CA and Meacham TN (1969) Reproductive efficiency on fourteen horse farms Journal of Animal Science 27 434-438

Jones EC (1970) The aging ovary and its influence on reproductive capacity Journal of Reproduction and Fertility Supplement 12 17-30

Kenney RM and Doig PA (1986) Endometrial biopsy. In Current Therapy in Theriogenology 2 pp 723-729 Ed. DA Morrow. WB Saunders, Philadelphia

Lang JA and Leech FB (1975) The frequency of infertility in Thoroughbred mares Journal of Reproduction and Fertility Supplement 23 307-310

Legay JM and Pontier D (1985) (Age-fecundity relation in a population of domestic cats, Felis catus.) Relation age-fecondité dans les populations de chats domestiques, Felis catus Mammalia 49 395-402

Levran D, Ben-Rafael Z, Ben-Shlomo I, Nebel L, Dor J and Mashiach S (1991) Aging of endometrium and oocytes: observations on conception and abortion rates in an egg donation model Fertility and Sterility 56 1091-1094

Mattheij JA and Swarts JJ (1991) Quantification and classification of pregnancy wastage in 5-day cyclic young through middle-aged rats Laboratory Animals 25 30-34

Navot D, Bergh PA, Williams MA, Garrisi GJ, Guzman I, Sandler B and Grunfield L (1991) Poor oocyte quality rather than implantation failure as a cause of age-related decline in female fertility Lancet 337 1375-1377

Neely DP (1983) Evaluation and therapy of genital disease in the mare. In Equine Reproduction pp 40-56 Ed. JP Hughes. Veterinary Learning Systems, Trenton

Oguri N and Tsutsumi Y (1972) Non-surgical recovery of equine eggs, and an attempt at non-surgical egg transfer in horses Journal of Reproduction and Fertility 31 187-195

Osoro K and Wright IA (1992) The effect of body condition, live weight, breed, age, calf performance, and calving date on reproductive performance of spring-calving beef cows Journal of Animal Science 70 1661-1666

Pascoe DR, Liu IKM, Spensley MS and Hughes JP (1985) Effect of endometrial pathology on the success of non-surgical embryo transfer Equine Veterinary Joumal, Supplement 3 108-110

Rotsztejn DA, Ord T, Balmaceda JP and Asch RH (1992) Variables which influence the selection of an egg donor Human Reproduction 7 59-62

Sauer MV, Paulson RJ and Lobo RA (1992) Reversing the natural decline in human fertility: an extended clinical trial of oocyte donation to women of advanced reproductive age Journal of the American Medical Association 268 $1275-1279$

Squires EL, Garcia RH and Ginther OJ (1985) Factors affecting success of equine embryo transfer Equine Veterinary Journal Supplement 3 92-95

Villahoz MD, Squires EL, Voss JL and Shideler RK (1985) Some observations on early embryonic death in mares Theriogenology 23 915-923

Weber JA, Freeman DA, Vanderwall DK and Woods GL (1991a) Prostaglandin E2 secretion by oviductal transport-stage equine embryos Biology of Reproduction 45 8-11

Weber JA, Freeman DA, Vanderwall DK and Woods GL (1991b) Prostaglandin E2 hastens oviductal transport of equine embryos Biology of Reproduction 45 I-3

Weber JA, Woods GL, Freeman DA and Vanderwall DK (1992a) Prostaglandin $\mathrm{E}_{2}$-specific binding to the equine oviduct Prostaglandins 43 61-65

Weber JA, Woods GL, Freeman DA and Vanderwall DK (1992b) Prostaglandin $E_{2}$ secretion by day- 6 to day-9 equine embryos Prostaglandins 43 55-59

Wimmers MS and Van der Merwe JV (1988) Chromosome studies on early human embryos fertilized in vitro Human Reproduction 3 894-900

Woods GL, Baker CB, Hillman RB and Schlafer DH (1985) Recent studies relating to early embryonic death in the mare Equine Veterinary joumal, Supplement 3 104-107

Woods GL, Baker CB, Baldwin JO, Ball BA, Bilinski JL, Cooper WL, Ley WB, Mank EC and Erb HN (1987) Early pregnancy loss in broodmares Journal of Reproduction and Fertility Supplement 35 455-459 